\title{
Relationship between Anxiety Score and Erythrocyte Sedimentation Rate (ESR) in Hemodialysis Patient
}

\author{
Rohmaningtyas Hidayah Setyaningrum', \\ Debree Septiawan'), Jhonny Prambudi Batong') \\ ${ }^{1)}$ Teaching Staff of Psychiatry Department, Faculty of Medicine, Universitas Sebelas Maret/ \\ Dr. Moewardi General Hospital, Surakarta \\ ${ }^{2)}$ Residency Program of Psychiatry Department, Faculty of Medicine, Universitas Sebelas Maret/ \\ Dr. Moewardi General Hospital, Surakarta
}

Background: Anxiety in hemodialysis patients often impaired quality of life. Complex interaction between Chronic Kidney Disease (CKD) and anxiety are dynamic and multifactorial, including socio-economic, lifestyle and biological factors. Biological factors are closely related to anxiety in CKD including the immune system, inflammatory pathways of disorders of Hypothalamic-Pituitary-Adrenal Axis (HPA). Erythrocyte sedimentation rate (ESR) is one of the non-specific inflammatory marker that show the degree of inflammatory reaction, Neutrophil-Lymphocyte Ratio (NLR) and Platelet-Lymphocyte Ratio (PLR) also found as an easy and inexpensive measureable marker to show the degree of inflammation. This study aimed to examine relationship between anxiety and hematology inflammation markers in hemodialysis patient.

Subjects and Method: This was an observational study with a cross-sectional design. The study was conducted at Dr. Moewardi general hospital, Surakarta, Central Java. A sample of 30 hemodialysis patients was selected for this study. The dependent variables were ESR, NLR, and PLR. The independent variable was anxiety. Anxiety was measured by Taylor Manifest Anxiety Scale (TMAS).
Data on ESR, NLR, and PLR, were measured using an assessment from RAND Corporation. The data were analyzed by a multiple linear regression.

Results: Anxiety increased NLR and it was marginally significant $(b=0.37 ; 95 \% \mathrm{CI}=$ 0.01 to $0.22 ; p=0.080)$. Anxiety decreased ESR and it was statistically significant $(b=-$ $0.57 ; 95 \% \mathrm{CI}=-0.02$ to $0.01 ; \mathrm{p}<0.001) . \mathrm{An}-$ xiety decreased PLR $(b=-0.16 ; 95 \% \mathrm{CI}=-0.02$ to $0.01 ; \mathrm{p}=0.440$ ) and duration of hemodialysis $(b=-0.27 ; 95 \% \mathrm{CI}=-0.03$ to $0.01 ; \mathrm{p}=$ o.167), but they were statistically non-significant.

Conclusion: Anxiety increases NLR. Anxiety decreases ESR, PLR, and duration of hemodialysis.

Keywords: chronic kidney disease, hemodialysis, hematology markers, inflammation

\section{Correspondence:}

Rohmaningtyas Hidayah Setyaningrum. Department of Psychiatry, Faculty of Medicine, Universitas Sebelas Maret/ Dr. Moewardi General Hospital, Surakarta, Central Java. Email: astitdr@gmail.com.

\section{Cite this as:}

Setyaningrum RH, Septiawan D, Batong JP (2020). Relationship between Anxiety Score and Erythrocyte Sedimentation Rate (ESR) in Hemodialysis Patient. Indones J Med. 05(02): 109-115. https://doi.org/10.26911/theijmed.2020.05.02.03

cc (i) (-) Indonesian Journal of Medicine is licensed under a Creative Commons

EY NG SA Attribution-NonCommercial-ShareAlike 4.o International License.

BACKGROUND

Chronic kidney disease (CKD) is damage in renal structure or function which has now become a serious public health problem
(Iwagami et al., 2017) and has an effect on almost $10 \%$ of the global population (Bautovich et al., 2014). Patients with end-stage kidney disease will face complications in all 
organ systems and common psychiatric complications are depression, anxiety, dementia, delirium, coping difficulties and marital or family problems (Valsaraj et al., 2016).

Anxiety in patients with chronic kidney disease often occurs together with depression and even worsens symptoms of depression and impaired quality of life. Both depression and anxiety are predictors of morbidity and mortality in patients undergoing hemodialysis, and are responsible for medication adherence and decreasing their immunity and nutritional status. From a cross sectional study of 200 stage III CKD patients to V-D in Haryana state, India, found $71 \%$ prevalence of anxiety (Aggarwal et al., 2017).

Previous studies have examined several markers that can be used to assess inflammation in patients suffering from $\mathrm{CKD}$, including Interleukin (IL), Tumor Necrosis Factor- $\alpha$ (TNF- $\alpha$ ), C-Reactive Protein (CRP), Sedimentation Rate (ESR), neutronphil-lymphocyte ratio (NLR) and thrombocyte-lymphocyte ratio (PLR) with meaningful results (Turkmen et al., 2017, Lopresti et al., 2014, Zahed et al., 2017). However, no studies have examined the relationship between hematologic inflammatory markers, namely ESR, NLR, and PLR in CKD patients who experience anxiety and undergo hemodialysis therapy. The aim of this study was to find differences and the relationship between changes in anxiety scores and hematologic inflammatory markers in CKD patients undergoing hemodialysis therapy.

\section{SUBJECTS AND METHOD}

\section{Study design}

This was a cross sectional study conducted at the Hemodialysis Unit of Dr. Moewardi Hospital, Surakarta, Central Java, in October 2018

\section{Population and Sample}

A total of 30 hemodialysis patients in the Hemodialysis Unit Dr. Moewardi hospital, Surakarta, were selected by purposive sampling.

Patients whose body temperature was above $37.4^{\circ} \mathrm{C}$ or below $36^{\circ} \mathrm{C}$, history of severe (psychotic) mental disorders, substance and alcohol abuse and those who have been diagnosed and underwent therapy for depression and anxiety, taking antiinflammatory drugs or steroids ( $<72$ hours since last taking the medicine), and cancer patient and have blood disorder were excluded.

\section{Study variables}

The dependent variables were ESR, NLR, and PLR. The independent variable was anxiety.

\section{Operational definition of variables}

Anxiety score examined using The Taylor Manifest Anxiety Scale (TMAS), was a validated measure of anxiety, with a score limit defined by 2 anxiety scales based on TMAS, measurement results:

Score $<21$ : without anxiety

Score $\geq 21$ : with anxiety

Erythrocyte sedimentation rate was a measurement of plasma viscosity by assessing the tendency of red blood cells to aggregate and settle in varying plasma viscosity over a period of 1 hour (in mm / hour).

\section{Clinical measurement}

The instrument used to examine anxiety scores is TMAS (Taylor Manifest Anxiety Score). The scale was created by James Taylor and is one form of psychological inventtory test used to determine the level of anxiety. The TMAS scale has been translated into Indonesian, and is often used in study to determine the subject's anxiety level as a general reaction to his inability to overcome problems or reactions to the absence of security, 
The validity and reliability test results for anxiety instruments (TMAS) shows the value of instrument reliability/ Cronbach's Alpha of 0.846 (Arismawati, 2016) And for the inflammatory biomarker were examined at Prodia Laboratory, for a complete blood counts, a quantitative blood check tool and a leukocyte difference count method that works automatically for clinical diagnostic in the form of blood analyzer with impedance method and for ESR is westergren modification method is used with the infrared barrier. The inspection parameters have been accredited SNI ISO 15189 by KAN with certificate no. LM-033IDN.

\section{Statistical analysis}

Sample characteristics were described in univariate analysis. Multivariate analysis was conducted by a multiple linear regression.

\section{Research ethics}

The study was conducted after passing the ethical review and received permission from the Head of Psychiatry Section of the Faculty of Medicine, Universitas Sebelas Maret/ Dr. Moewardi hospital, Surakarta, obtained the Ethical Clearance from Ethics

Table 1. Demographic Sample Data

\begin{tabular}{llcc}
\hline \multicolumn{1}{c}{ Variables } & N & \% \\
\hline Gender & Male & 14 & 1.05 \\
Age & Female & 16 & 1.75 \\
& Adolescent & 1 & \\
& Young adult & 10 & \\
Duration of hemodialysis & Old adult & 17 & 1.07 \\
\multirow{2}{*}{ Education } & Elderly & 2 & \\
& $<3$ Months & 8 & 0.97 \\
& $\geq 3$ Months & 22 & \\
& Not Educated & 1 & \\
Income & Elementary & 5 & \\
& Junior High School & 7 & \\
& Senior High School & 10 & \\
& Bachelor Degree & 6 & 0.49 \\
\hline
\end{tabular}

Research Committee of Dr. Moewardi hospital, Surakarta. Before conducting the study, patients were given an explanation of the objectives and activities of this study. Study subjects gave written informed consent.

The study was conducted with reference to the basic principles of bioethics. In accordance with the principle of respect for autonomy, the authors ask prospective subjects to sign a study permit after they get sufficient explanation and are given the opportunity to ask questions that are still unclear. There is no compulsion to follow the study. Subjects can also stop participating in study if they feel negative things that arise during the study. The principle of justice is fulfilled because it does not distinguish individuals, for example gender, ethnicity, and religion. Thus, the principle of non-maleficence has also been fulfilled, that is no negative impacts were found on participants arising from this study.

\section{RESULTS}

1. Sample characteristics

Table 1 described demographic sample data. 
Setyaningrum et al./ Anxiety score and erythrocyte sedimentation rate

In this study, male patients were 14 samples (46.67\%) while women were 16 samples (53.33\%). The most age group of patients was 41-60 years (56.67\%). Most of patients had highest education in senior high school (33.33\%). Patients had an average income of less than 5 million rupiahs (Table 1).

Table 2. Biomarker differences in blood inflammation in patients with anxiety and not anxiety

\begin{tabular}{ccccc}
\hline Independent & Mean & \multicolumn{2}{c}{ 95\% CI } & \multirow{2}{*}{ p } \\
\cline { 3 - 4 } Variables & Difference & Upper limit & Lower limit & \\
\hline ESR & 30.14 & 49.63 & 10.44 & 0.004 \\
NLR & -1.01 & -0.34 & -2.35 & 0.134 \\
PLR & -4.28 & -7.84 & -16.39 & 0.463 \\
\hline
\end{tabular}

From Table 2, we found a significant difference in ESR biomarkers between patients who experienced anxiety and those who

Table 3. The results of multiple linear regression on the relationship between anxiety score and erythrocyte sedimentation rate (ESR) in hemodialysis patient

\begin{tabular}{lcccc}
\hline \multirow{2}{*}{ Independent Variables } & \multirow{2}{*}{$\mathbf{b}$} & \multicolumn{2}{c}{ 95\% CI } & \multirow{2}{*}{$\mathbf{p}$} \\
\cline { 3 - 4 } & & Lower limit & Upper limit & $<0.001$ \\
ESR & -0.57 & -0.02 & -0.01 & 0.080 \\
NLR & 0.37 & -0.01 & 0.22 & 0.440 \\
PLR & -0.16 & -0.02 & 0.01 & 0.4290 \\
Age & 0.05 & -0.01 & 0.01 & 0.290 \\
Duration of HD & -0.27 & -0.03 & 0.01 & 0.167 \\
\hline
\end{tabular}

\section{Association between anxiety score and ESR}

From Table 3, there was an association between anxiety scores and ESR compared with NLR and PLR, age of sample, and duration of the HD patient.

Anxiety increased NLR and it was marginally significant $(b=0.37 ; 95 \% \mathrm{CI}=$ 0.01 to $0.22 ; \mathrm{p}=0.080$ ).

Anxiety decreased ESR and it was statistically significant $(b=-0.57 ; 95 \% \mathrm{CI}=-$ 0.02 to $0.01 ; \mathrm{p}<0.001$ ).

Anxiety decreased PLR (b= -0.16; $95 \% \mathrm{CI}=-0.02$ to $0.01 ; \mathrm{p}=0.440$ ) and duration of hemodialysis $(b=-0.27 ; 95 \% \mathrm{CI}=-$ 0.03 to $0.01 ; \mathrm{p}=0.167)$, but they were statistically non-significant.

\section{DISCUSSION}

Inflammation is a biological process that has been increasingly researched in chronic mental and physical diseases over the past did not but not for the neutrophil lymphocyte ratio and platelet lymphocyte ratio biomarkers. decade, because it has a clear role in its pathophysiology. Although stress exposure can directly lead to increased inflammation in the absence of pathogens, activation of the HPA axis and the autonomic nervous system also modulates the inflammatory process due to stress reciprocally (Michopoulos et al., 2016). Prolonged exposure to stressful stimuli that cause fear and anxiety will activate both central and peripheral immune cells and induce an inflammatory response to $\mathrm{NLRP}_{3}$, a multiprotein complex that processes activation of inflammatory cytokines, and leads to the release of IL-1 $\beta$ (Alcoce et al., 2017). In glial cells, IL-1 $\beta$ induces NF-B transcripttional activity which results in increased circulating concentration of IL-6 (Michopoulos et al., 2016; Alcocer et al., 2017) and Tumour Necrosis Factor (TNF)- $\alpha$ (Miller and Raison, 2016). The release of these pro-inflammatory cytokines will activate $\mathrm{CRH}$ in the 
hypothalamus which then stimulates the secretion of adrenocorticotropic hormone (ACTH) and starts HPA-axis activity by releasing glucocorticoids (cortisol) into the circulation (Melmed and Jameson, 2015).

The condition of uremia also affects the immune response of the patient which causes a failure of the immune response caused by:

- Decreased phagocytic function of granulocytes and monocytes / macrophages.

- Defects in the antigen presenting cells function.

- Decreased number and antibodies that produce B lymphocytes

- Increased T-cell reshuffle and apoptosis which leads to a decrease in $\mathrm{CD} 4+$ and CD 8+ T-lymphocytes.

- Failure of cellular immunity.

The mechanism of the exact cause of this disorder is not entirely clear because there are many factors that contribute to this abnormality (Vaziri, 2012).

ESR is a marker of acute phase reactions. When inflammation occurs, the ESR change due to an increase in the concentration of fibrinogen and alpha globulin. This test mainly measures plasma viscosity by assessing the tendency of red blood cells to aggregate and settle in plasma viscosity that varies over a period of time (usually 1 hour) in millimeters $(\mathrm{mm})$ /hour (Bray et al., 2016, Harrison, 2016).

The high ESR is found in depressed patients compared to healthy people (Lopresti et al., 2014; Nicolau, 2017). This is supported by the statement that chronic inflammation plays an important role in the pathophysiology of depression (Zahed et al., 2017). Due to the study it provides that chronic inflammation in several diseases can lead to anxiety and depression applies reciprocally for a worsening of the diseases / disorders.
In HD patient there was a lot of stress stimulus such as in internal and external stimulus such as thought for the diseases, how the patient feels about the diseases, etc. All of the stressor stimulus can lead to anxiety, depression or both. PLR and NLR is negative maybe because of the inflammation was not acute, as mention in previous study that lymphocyte tend to high in an acute inflammation process but not in chronic.

In several studies that have been carried out, ESR is a sign of increased inflammation in patients with CKD other than CRP, interleukin, and ferritin, which leads to worsening depression followed by malnutrition, atherosclerosis, cardiovascular disease and death in patients with late stage kidney disease (Zahed et al., 2017). Furthermore, in patients undergoing HD therapy, the ESR value also increased significantly (Bilen et al., 2014).

There was a difference between the ESR biomarker results among subjects who experienced anxiety and those who did not and found an association between ESR and anxiety scores, but for NLR and PLR there was no association with anxiety in hemodialysis therapy. Many things can affect the biomarkers of hematological inflammation.

\section{AUTHOR CONTRIBUTION}

Rohmaningtyas Hidayah Setyaningrum and Jhonny Prambudi Batong designed the study. Debree Septiawan, Jhonny Prambudi Batong and Rohmaningtyas Hidayah Setyaningrum helped to conceive and design the evaluation. Jhonny Prambudi Batong and Debree Septiawan managed the literature searches and do the statistical analysis. Jhonny Prambudi Batong helped to literature review and collected the clinical data. Rohmaningtyas Hidayah Setyaningrum and Jhonny Prambudi Batong interpreted the clinical data and wrote the first draft of the 
Setyaningrum et al./ Anxiety score and erythrocyte sedimentation rate

manuscript. All authors contributed to and have approved the final manuscript.

\section{CONFLICT OF INTEREST}

All authors declare that they have no conflict of interests.

\section{FUNDING AND SPONSORSHIP}

This study was not supported by any organization or institution. All expenses from this study are borne by all authors.

\section{ACKNOWLEDGEMENT}

The authors acknowledge the support of Dr. Moewardi General Hospital Surakarta. Thank you for the training section and the hemodialysis room team Dr. Moewardi General Hospital Surakarta. Thanks to Prodia for providing the assistance of examiners for laboratory examinations.

\section{REFERENCE}

Aggarwal HK, Jain D, Dabas G, Yadav RK (2017). Prevalence of depression, anxiety and insomnia in chronic kidney disease patients and their co-relation with the demographic variables. Pril (Makedon Akad Nauk Umet Odd Med Nauki). 38(2):35-44. https://doi.org/10.1515/prilozi-2017-0020

Alcocer-Gómez E, Castejón-Vega B, Cordero MD (2017). Stress-Induced NLRP3 Inflammasome in Human Diseases. Adv Protein Chem Struc Biol. 108: 127-162. https://doi.org/10.1016/bs.apcsb.2017.02.002

Arismawati (2016). Hubungan antara pemaafan (forgiveness) dengan kecemasan (anxiety) pada remaja yang orangtuanya bercerai. Available: http://repository.upi.edu/25239/.

Bautovich A, Katz I, Smith M, Loo CK, Harvey SB (2014). Depression and chronic kidney disease: A review for clinicians. Australian \& New Zealand
J Psychiatry. 48(6): 530-541. https://doi.org/10.1177/0004867414528589

Bilen Y, Cankaya E, Keles M, Gulcan E, Uyanik A, Turkeli M, Albayrak B, Yildirim R (2014). Does decreased mean platelet volume predict inflammation in chronic renal failure, dialysis, and transplanted patients?. Ren Fail. 36(1): 69-72. https://doi.org/10.3109/o886022X.2013.832310

Bray C, Bell LN, Liang H, Haykal R, Kaiksow F, Mazza JJ, Yale SH (2016). Erythrocyte sedimentation rate and Creactive protein measurements and their relevance in clinical medicine. Wilconsin Med J. 115(6): 17-21. https://www.ncbi.nlm.nih.gov/pubmed/29 094869

Harrison M (2015). Erythrocyte sedimentation rate and C-reactive protein. Australian Prescriber. 38(3): 93-94. Doi: 10.18773/austprescr.2015.034

Iwagami M, Tomlinson LA, Mansfield KE, McDonald HI, Smeeth L, Nitsch D (2017). Prevalence, incidence, indication, and choice of antidepressants in patients with and without chronic kidney disease: a matched cohort study in UK Clinical Practice Research Datalink. Pharmacoepidemiol Drug Saf. 26(7): 792-801. https://doi.org/10.1002/pds.4212

Lopresti AL, Maker GL, Hood SD, Drummond PD (2014). A review of peripheral biomarkers in major depression: The potential of inflammatory and oxidative stress biomarkers. Prog Neuropsychopharmacol Biol Psychiatry. 48: 102-11. https://doi.org/10.1016/j.pnpbp.2013.09.017

Gay LR, Diehl PL (1992). Research methods for business and management. Pennsylvania State University: Macmillan Publishing Company. 
Michopoulos V, Powers A, Gillespie CF, Ressler KJ, Jovanovic T (2016). Inflammation in fear- and anxiety-based disorders: PTSD, GAD, and beyond. Neuropsychopharmacology. 42(1): 254-270. https://doi.org/10.1038/npp.2016.146

Melmed S, Jameson LJ (2015). Anterior pituitary: Physiology of pituitary hormones," in Harrison's Principles of Internal Medicine, Nineteenth ed., New York: McGraw-Hill Education.

Miller AH, Raison CL (2016). The role of inflammation in depression: from evolutionary imperative to modern treatment target. Nature Reviews Immunology. 16(1):22-34. https://doi.org/10.1038/nri.2015.5

Nicolau J, Simo R, Sanchís P, Ayala L, Fortuny R, Masmiquel L (2017). Effects of depressive symptoms on clinical outcomes, inflammatory markers and quality of life after a significant weight loss in a bariatric surgery sample. Nutrición Hospitalaria. 34(1): 81-87. https://doi.org/10.20960/nh.979

Turkmen K, Erdur FM, Ozcicek F, Ozcicek A, Akbas EM, Ozbicer A, Demirtas L,
Turk S, Tonbul HZ (2013). Platelet-tolymphocyte ratio better predicts inflammation than neutrophil-to-lymphocyte ratio in end-stage renal disease patients. Hemodialysis Internationa. 17(3): 391-396. https://doi.org/10.1111/hdi.12040

Valsaraj BP, Bhat SM, Latha KS (2016). Cognitive behaviour therapy for anxiety and depression among people undergoing haemodialysis: a randomized control trial. Journal of Clinical and Diagnostic Research. 10(8): VCo6-VC10. https://dx.doi.org/10.7860\%2FJCDR\%2F2O16\%2F18959.83 83.

Vaziri ND, Pahl MV, Crum A, Norris K (2012). Effect of uremia on structure and function immune system. Journal Renal Nutrition. 22(1): 149-156. https://doi.org/10.1053/j.jrn.2011.10.020

Zahed NS, Sharifi M, Karimi M, Nikbakht H (2017). Impact of sertraline on serum concentration of CRP in Hemodialysis patients with depression. Journal of Renal Injury Prevention. 6(1):65-69. https://dx.doi.org/10.15171\%2Fjrip.2 017.12 